Sains Malaysiana 50(3)(2021): 769-778

http://dx.doi.org/10.17576/jsm-2021-5003-18

\title{
Antihypertensive Activities of Standardised Moringa oleifera Lam. (Merunggai) Extracts in Spontaneously Hypertensive Rats
}

(Aktiviti Antihipertensi Menggunakan Ekstrak Moringa oleifera Lam. (Merunggai) Piawai pada Tikus Hipertensi Secara Spontan)

Endang Kumolosasi, Cheng Chen Wei, Anis Zafiqa Abdullah, Nur Syahirah Abd Manap, Woon Lee Lee, Mohd Hanif Yusuf, Lo Shin Ying, Fhataheya Buang, Mazlina Mohd Said, Hazni Falina Mohamad \& MALINA JASAMAI*

\begin{abstract}
In recent years, Moringa oleifera has received commercial interest for its blood pressure (BP)-lowering effect. The objectives of this study were to investigate the hypotensive, diuretic, and angiotensin converting enzyme (ACE)-inhibitory activities of M. oleifera ethanolic and aqueous extracts. Spontaneously hypertensive (SH) and normotensive (NT) rats were fed the ethanolic and aqueous extracts at a dose of $1000 \mathrm{mg} / \mathrm{kg}$ each for 14 days. The rats were allocated to 12 groups of five rats each. Systolic and diastolic BP were measured, and urine was collected. All extracts, except the aqueous stem extract, significantly reduced systolic and diastolic BP in SH rats, but none of the extracts showed significant hypotensive effects on NT rats. The ethanolic leaf extract (ELE) caused significant diuresis. Moreover, most of the extracts inhibited ACE activity significantly at 40 and $80 \mu \mathrm{g} / \mathrm{mL}$. ELE, aqueous leaf extract (ALE), and ethanolic pod extract

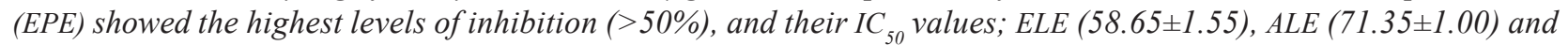
EPE (54.04 1.00) were determined. The hypotensive effect observed was achieved either by diuretic or ACE-inhibitory activity. The active extracts are worthy of further investigation, as they have the potential to be developed as dietary supplements for pre-hypertensive individuals.
\end{abstract}

Keywords: ACE inhibition; diastolic blood pressure; diuretic; Moringa oleifera; systolic blood pressure

ABSTRAK

Dalam beberapa tahun kebelakangan ini, Moringa oleifera telah mendapat perhatian komersial untuk menurunkan tekanan darah. Objektif kajian ini adalah untuk mengkaji kesan hipotensi, aktiviti diuretik dan penukaran enzim angiotensin (ACE) ekstrak etanol dan ekstrak akueus M. oleifera. Ekstrak etanol dan ekstrak akueus diberi makan kepada tikus hipertensi secara spontan (SH) dan tikus normotensif (NT) pada dos $1000 \mathrm{mg} / \mathrm{kg}$ selama 14 hari. Dua belas kumpulan tikus digunakan dengan lima ekor tikus dalam setiap kumpulan Tekanan darah (TD) sistolik dan diastolik diukur dan urin dikumpul. Aktiviti perencatan ACE oleh ekstrak juga dikaji. Kesemua ekstrak kecuali ekstrak akueus batang menunjukkan pengurangan ketara TD sistolik dan diastolik pada SH tetapi tidak ada ekstrak yang menunjukkan kesan hipotensi yang signifikan terhadap NT. Ekstrak etanol daun (ELE) menunjukkan kesan diuretik yang ketara. Kebanyakan ekstrak menghalang aktiviti ACE dengan ketara pada 40 dan $80 \mu \mathrm{g} / \mathrm{mL}$. Ekstrak akueus daun (ALE) dan ekstrak etanol lenggai (EPE) menunjukkan tahap perencatan tertinggi (> 50\%) dan nilai IC ${ }_{50}$ nya; ELE (58.65 \pm 1.55$)$,

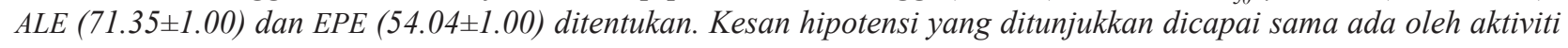
diuretik atau perencatan ACE. Ekstrak yang aktif patut dikaji dengan lebih lanjut kerana ia mempunyai potensi untuk dikembangkan sebagai makanan tambahan bagi individu pra-hipertensi.

Kata kunci: Diuretik; Moringa oleifera; perencatan ACE; tekanan darah sistolik; tekanan darah diastolik

\section{INTRODUCTION}

Obesity, dyslipidaemia, and hypertension have been reported as the most prevalent risk factors associated with cardiovascular diseases in Malaysia (Amiri et al. 2014). Alarmingly, despite awareness and improvements in the health care system, the prevalence of hypertension in Malaysian adults aged over 30 years has been a rising trend from 2006 to 2015 (Ab Majid et al. 2018). Hypertensive patients, defined as those with persistent elevation of systolic blood pressure (BP) of $140 \mathrm{mmHg}$ or greater and/or diastolic BP of $90 \mathrm{mmHg}$ or greater $(\mathrm{MOH}$ 2013), are managed with pharmacological treatments. In contrast, pre-hypertensive individuals, defined as those with systolic BP of 120 to $139 \mathrm{mmHg}$ or diastolic BP of 
80 to $89 \mathrm{mmHg}$, are managed with non-pharmacological treatments, including dietary supplements (MOH 2013). Herbal supplements such as ginseng, garlic, ginger, gingko biloba, echinacea, and hawthorn have gained popularity for preventing cardiovascular diseases. Locally, merunggai (Malay) or Moringa oleifera Lam (syn. M. ptregosperma Gaertn.), which belongs to the Moringaceae family, has been reported to exert negative inotropic effect (Dangi et al. 2002) and diuretic activity (Cáceres et al. 1992).

The history of $M$. oleifera dates back to $150 \mathrm{BC}$, when ancient kings and queens used its leaves and fruits in their diet for extra energy and to relieve stress and pain (Mahmood et al. 2010). Most of the plant parts have been used traditionally in Southeast Asia for various ailments, including as a cardiac circulatory tonic and diuretic (Khare 2007; Nadkarni 2009). M. oleifera has high nutritional value: the leaves are rich in vitamins A and C (Shankeret al. 2007), and the seeds contain high amounts of magnesium and calcium (Amaglo et al. 2010). The leaves and young pods are usually used in cooking. M. oleifera is also rich in simple sugars (glucosinolates and isothiocyanates) (Fahey et al. 2001), alkaloids (moringin and moringinine) (Nellis 1997), flavonoids (kaempferol, rhamnetin, isoquercitrin, and kaempferitrin) (Siddhuraju \& Becker 2003), amino acids (methionine, cystine, tryptophan, and lysine) (Lim 2012), and fatty acids (oleic oils and tocopherols) (Rossell \& Pritchard 1991). The diverse bioactive compounds present in this highly valued plant might contribute to the various pharmacological activities observed. Moreover, $M$. oleifera, which has shown good safety profiles, is abundant in Malaysia (Asare et al. 2012).

The hypotensive effect of $M$. oleifera has been reported in previous studies (Faizi et al. 1998, 1994), and may be attributed to the presence of glycosides (thiocarbamate, isothiocyanate, and mustard oil) (Faizi et al. 1995), methyl $p$-hydroxybenzoate, $\beta$-sitosterol (Faizi et al. 1998), niazinin A, niazinin B, niazimicin, and both niazimin A and B (Faizi et al. 1994) in the pods, seeds, roots, and leaves. Different parts of $M$. oleifera have also been shown to exhibit diuretic activity (Cáceres at al. 1992). However, information on the hypotensive effect of the stems and twigs is still lacking. Moreover, the action mechanism of the blood pressure-lowering effect has not been fully explored, and little is known on the effect of these plant parts on non-hypertensive individuals.

Ethanolic and aqueous extracts of the stems and twigs of $M$. oleifera might show a similar hypotensive effect as that reported for other plant parts (Faizi et al. 1998, 1995, 1994). This effect might be due to diuresis or disruption in the renin-angiotensin pathway, as these are among the common action mechanisms of antihypertensive agents. The hypotensive effect might not be observed in non-hypertensive individuals, as in the case of garlic supplements (Wang et al. 2015). In this study, the hypotensive effects of different $M$. oleifera ethanolic and aqueous extracts were evaluated in spontaneously hypertensive (SH) and normotensive (NT) rats. The diuretic and angiotensin converting enzyme (ACE)-inhibitory activities of these extracts were also investigated.

\section{MATERIALS AND METHODS}

\section{RATS AND CHEMICALS}

SH rats were purchased from the Animal Unit of University Malaya, and Sprague-Dawley rats were purchased from the Animal Unit of Universiti Kebangsaan Malaysia (UKM). The reference standards used in this study were purchased from Wuhan ChemFaces Biochemical Co., Ltd. (Wuhan, China) [ $\beta$-sitosterol, 98\% purity by high-performance liquid chromatography (HPLC); campesterol, 98\% purity by HPLC], Extrasynthese (Lyon, France) (kaempferol-3-O-rutinoside, 98\% purity by HPLC; stigmasterol, 90\% purity by HPLC; chlorogenic acid, 99\% purity by HPLC), and Sigma Aldrich Malaysia (octacosanoic acid, 98\% purity by HPLC; lisinopril, 98\% purity by HPLC; tragacanth). The positive controls for the in vivo study were clinically used drugs: perindopril 5 mg (Coversyl ${ }^{\circledR}$; Servier), irbesartan 150 mg (Aprovel ${ }^{\circledR}$; Sanofi Aventis), and hydrochlorothiazide $12.5 \mathrm{mg}$ (Hydrochlorothiazide ${ }^{\circledR}$; Royce Pharma).

\section{PREPARATION OF PLANT PARTS}

M. oleifera plant parts (the leaves, twigs, stems, roots, pods, and seeds) were obtained from a farm in Kuala Terengganu, Terengganu in October 2015. The plant was identified and authenticated by Professor Emeritus Dato' Dr. Abdul Latiff Mohamad of the Faculty of Science and Technology, UKM, and a voucher specimen (HF-133) was deposited in the UKM Herbarium. The plant parts were cut into small pieces, dried, ground, and stored at room temperature $\left(29^{\circ} \mathrm{C}\right)$ until use.

The ground $M$. oleifera plant parts were extracted with water and ethanol. Water extraction was performed by boiling plant materials $(100 \mathrm{~g})$ in distilled water $(0.15 \mathrm{~L})$ for $6 \mathrm{~h}$. The extracts were filtered and stored at $-80{ }^{\circ} \mathrm{C}$ for 3 days prior to being freeze-dried (Rathi et al. 2006), and the powdered extracts obtained were stored at $-20{ }^{\circ} \mathrm{C}$ until use. Ethanol extraction was performed by maceration. Plant parts $(500 \mathrm{~g})$ were soaked in $95 \%$ ethanol (at a ratio of one plant part to six parts of ethanol) for 3 days at room temperature $\left(29^{\circ} \mathrm{C}\right)$. The extracts were filtered, and the filtrate was concentrated under vacuum to obtain a dark green gummy extract. The residues were macerated twice. The extracts were stored at $4{ }^{\circ} \mathrm{C}$ until use.

Tragacanth suspension was prepared by dissolving $3 \mathrm{~g}$ of tragacanth powder in $300 \mathrm{~mL}$ distilled water prior 
to preparation of test samples and controls. Tragacanth suspension was used as a negative control (NC). Next, plant part extracts $(4.9 \mathrm{~g})$, perindopril [positive control 1 (PC1)] (9.8 mg), irbesartan [positive control 2 (PC2)] (98 mg), and hydrochlorothiazide (positive control [PC], $29.4 \mathrm{mg}$ ) were dissolved in $35 \mathrm{~mL}$ of $1 \%$ tragacanth before being fed to rats. Drug doses were calculated based on dose conversion from humans to animals (Laurence \& Bacharach 1964), and the dose used for the extracts was determined in a preliminary study conducted prior to the actual study.

\section{STANDARDISATION OF M. oleifera EXTRACTS}

Chemical markers were dissolved in HPLC-grade methanol to produce standard solutions of $1.0 \mathrm{mg} / \mathrm{mL}$ for $\beta$-Sitosterol, kaempferol-3- $O$-rutinoside, and stigmasterol as well as $0.5 \mathrm{mg} / \mathrm{mL}$ for chlorogenic acid and campesterol. Octacosanoic acid was prepared as a $0.5 \mathrm{mg} / \mathrm{mL}$ solution in methanol and chloroform (7:3). M. oleifera ethanolic and aqueous extracts were accurately weighed $(1.0 \mathrm{~g})$, dissolved in $10 \mathrm{~mL}$ distilled water, mixed thoroughly by vortexing, sonicated for $15 \mathrm{~min}$, and centrifuged for $5 \mathrm{~min}$ at $4000 \mathrm{rpm}$. The supernatant was collected and filtered with a $0.45-\mu \mathrm{m}$ membrane filter prior to injection into the HPLC column. A HPLC system (Waters 1515 Isocratic HPLC pump) with a dual wavelength absorbance detector (Waters 2487) was utilised to analyse the general profiles of phytochemical compounds in the plant extracts and to quantify the compound content. The HPLC column (5 $\mu \mathrm{m}$ C18 column, XBridge Reversed-Phase) was set at room temperature $\left(29^{\circ} \mathrm{C}\right)$ at a flow rate of $1.0 \mathrm{~mL} / \mathrm{min}$. HPLC-grade methanol and water were mixed at a ratio of 70:30 (v/v) and used as mobile phase. The mobile phase was filtered and degassed for $15 \mathrm{~min}$ before use. Samples $(20 \mu \mathrm{L})$ were injected with a running time of $10 \mathrm{~min}$, and peaks were detected at $205 \mathrm{~nm}$. The accuracy, precision, and specificity of the method were determined for method validation.

\section{DETERMINATION OF SYSTOLIC AND DIASTOLIC BP}

The research was conducted in accordance with the internationally accepted principles for laboratory procedures and care of animals as described in the European Community guidelines (EEC Directive of 1986; 86/609/EEC). The experimental procedure was approved by the UKM Animal Ethics Committee (FF/2016/ MALINA/18-MAY/754-MAY-2016-JAN.-2018) on 18th May 2016. Rats were maintained in the Faculty Animal House, caged in a group of three, and provided pelleted feed and water ad libitum. A 12-h dark and light cycle was maintained. Systolic and diastolic BP were measured using a CODA high-throughput tail-cuff system (CODA-HT2)
(Daugherty et al. 2009). Briefly, the infra-red warming platform was preheated at $32-35^{\circ} \mathrm{C}$, and a rat was allowed to enter freely into a plastic restraint of appropriate size on the platform. The nose cone on the restraint was adjusted, and the rat was left in the restraint without human handling for 10-15 min. An occlusion cuff was placed at the base of the tail, followed by a volume pressure recording cuff. The temperature of the tail was maintained at $32-35{ }^{\circ} \mathrm{C}$ throughout the experiment using a warming cover.

In a preliminary study to determine an effective dose, SH rats were allocated into four treatment groups of three rats each. Each group was treated with PC1, NC, low-dose $(500 \mathrm{mg} / \mathrm{kg})$ M. oleifera ethanolic leaf extract (ELE), or high-dose $(1000 \mathrm{mg} / \mathrm{kg})$ ELE. Feeding of rats with doses higher than $1000 \mathrm{mg} / \mathrm{kg}$ was difficult owing to the viscosity of the extract. Rats were fed orally once daily for 7 consecutive days, and BP was measured on days 1 and 7 of the study.

In a preliminary study to determine the BP-lowering effects of $M$. oleifera extracts on NT rats, 18 SpragueDawley rats weighing 200-300 g were randomly divided into six groups of three rats each. NC, ELE, aqueous leaf extract (ALE), ethanolic twig extract (ETE), ethanolic seed extract (ESE), and ethanolic root extract (ERE) were administered to each group. Extracts and controls were administered to the rats by oral gavage once daily for 14 days. The administered volume of extract suspensions was adjusted daily according to the weight of rats (1 $\mathrm{mL} / 100 \mathrm{~g})$.

The BP-lowering effects of $M$. oleifera plant part extracts were investigated in 60 male adult SH rats weighing 200-300 g. They were randomly divided into 12 groups of five rats each. Each group of rats was fed NC, PC1, PC2, ELE, ALE, ETE, ethanolic pod extract (EPE), aqueous pod extract (APE), ESE, ethanolic stem extract (EEE), aqueous stem extract (AEE), or ERE. Five NT rats were used as controls in this study. Systolic and diastolic BP were measured prior to the administration of extracts and controls on day 1 and day 15 post-treatment. Reductions in systolic and diastolic BP were the differences between the values obtained on day 0 and those obtained on day 15 .

\section{EVALUATION OF DIURETIC ACTIVITY}

Diuretic activity was determined on day 14 of the study. Rats were deprived of food but not water for $18 \mathrm{~h}$ prior to urine collection. The groups receiving extracts and $\mathrm{NC}$ were fed as usual, and a group receiving positive control was fed hydrochlorothiazide. After the administration of extracts and controls, rats were placed individually in metabolic cages, and cumulative urine output was determined at hourly intervals for $5 \mathrm{~h}$. 


\section{ACE INHIBITION ASSAY}

The ACE-inhibitory activity of the extracts was determined using a method described by Agboola et al. (2010) with some modifications. Lisinopril (positive control), ELE, ALE, ETE, EPE, APE, ESE, EEE, AEE, and ERE were used in this study. Briefly, $80 \mu \mathrm{L}$ of the positive control and extracts $(4,8,10,20,40,60$, and $80 \mu \mathrm{g} / \mathrm{mL})$ were dissolved in $0.1 \mathrm{M}$ borate buffer containing $0.3 \mathrm{M}$ $\mathrm{NaCl}(\mathrm{pH}$ 8.3) and mixed with $20 \mu \mathrm{L}$ ACE solution (0.1 $\mathrm{U} / \mathrm{mL}$ ). The mixture was incubated at $37^{\circ} \mathrm{C}$ for $10 \mathrm{~min}$. Next, $200 \mu \mathrm{L}$ of $5.0 \mathrm{mM}$ hippuryl-histidyl-leucine substrate was added, and the enzyme-substrate mixture was further incubated for $30 \mathrm{~min}$ at $37{ }^{\circ} \mathrm{C}$. Enzymatic reaction was quenched by adding $0.05 \mathrm{M} \mathrm{HCl}(250 \mu \mathrm{L})$ to the reaction mixture. The produced hippuric acid was extracted by adding $1.7 \mathrm{~mL}$ ethyl acetate to the mixture, which was then shaken vigorously for $1 \mathrm{~min}$ and centrifuged for $5 \mathrm{~min}$ at $5000 \mathrm{rpm}$. The upper layer was placed in a vial and heated in a water bath to evaporate the ethyl acetate. The residue was dissolved in $1 \mathrm{~mL}$ distilled water, and absorbance was determined using a UV-visible spectrophotometer (Shimadzu UV Spectrophotometer UV1800) at $228 \mathrm{~nm}$. A blank sample containing $0.05 \mathrm{M} \mathrm{HCl}(50 \mu \mathrm{L})$ was prepared and used to calculate the percentage inhibition (Agboola et al. 2010).
$\%$ ACE inhibition $=($ blank absorbance - sample absorbance $)$

$\times 100 /$ blank absorbance

\section{STATISTICAL ANALYSIS}

Values obtained were analysed using PRISM software (5.0). Data are presented as mean \pm standard error of the mean (SEM) and statistical comparisons were conducted using the paired-sample $t$-test, one-way ANOVA, and Bonferroni post-hoc test. Significance was set at $p \leq 0.05$.

\section{RESULTS}

\section{STANDARDISATION OF M. oleifera EXTRACTS}

HPLC chromatograms of $M$. oleifera plant extracts (Table 1) showed the presence of different phytochemical compounds, which correspond to the respective standards used (chlorogenic acid, $\beta$-sitosterol, stigmasterol, campesterol, and kaempferol-3-O-rutinoside). The presence of the respective chemical markers was confirmed by spiking the extracts with the markers. Only extracts containing the phytochemical compounds mentioned were used in this study, namely ELE, ALE, ETE, EPE, APE, ESE, EEE, and AEE.

TABLE 1. Phytochemical compounds identified from Moringa oleifera plant part extracts by HPLC

\begin{tabular}{ccccc}
\hline $\begin{array}{c}\text { Phytochemical compounds/ } \\
\text { plant extracts }\end{array}$ & $\begin{array}{c}\text { Retention time } \\
(\mathrm{min})\end{array}$ & RSD $(\%)$ & Area (mAU) & $\begin{array}{c}\text { Concentration } \\
(\mathrm{mg} / \mathrm{mL})\end{array}$ \\
\hline Chlorogenic acid & $5.226 \pm 0.145$ & 0.014 & 40916458 & 1.000 \\
ELE & $6.515 \pm 0.040$ & 0.000 & 36608919 & 0.895 \\
ALE & $5.33 \pm 0.120$ & 0.013 & 83956154 & 1.026 \\
$\beta$-Sitosterol & $2.824 \pm 0.010$ & 0.025 & 2270104 & 1.000 \\
ETE & $2.817 \pm 0.003$ & 0.041 & 6437894 & 7.274 \\
EPE & $2.828 \pm 0.020$ & 0.008 & 30891887 & 12.807 \\
APE & $2.79 \pm 0.048$ & 0.025 & 25387830 & 11.095 \\
Stigmasterol & $4.278 \pm 0.003$ & 0.017 & 1899873 & 1.000 \\
ESE & $4.425 \pm 0.020$ & 0.016 & 7495848 & 3.952 \\
Campesterol & $4.276 \pm 0.003$ & 0.017 & 1955984 & 0.500 \\
ESE & $4.425 \pm 0.020$ & 0.016 & 6322866 & 1.918 \\
EEE & $3.150 \pm 0.007$ & 0.022 & 2230220 & 1.000 \\
AEE & $3.110 \pm 0.030$ & 0.023 & 240386 & 0.056 \\
\hline Kaempferol-3-O-rutinoside & $3.20 \pm 0.087$ & 0.022 & 527880 & 0.977 \\
\hline
\end{tabular}

ELE, ethanolic leaf extract; ALE, aqueous leaf extract; ETE, ethanolic twig extract; EPE, ethanolic pod extract; APE, aqueous pod extract; ESE, ethanolic seed extract; EEE, ethanolic stem extract; AEE, aqueous stem extract 


\section{BP-LOWERING EFFECTS OF THE EXTRACTS}

The parameters measured using the non-invasive tail-cuff method included systolic and diastolic BP. A preliminary study was conducted to determine the effective dose of the extract, and the results are presented in Figure 1. High-dose $(1000 \mathrm{mg} / \mathrm{kg})$ ELE significantly lowered the systolic $(133.3 \pm 4.53 \mathrm{~mm} \mathrm{Hg})(p \leq 0.001)$ and diastolic $(83.07 \pm 12.20 \mathrm{~mm} \mathrm{Hg})(p \leq 0.01) \mathrm{BP}$ of SH rats compared with that of the NC rats. The effect of high-dose ELE was comparable with that of the positive control, as no significant differences were observed. No significant reduction in systolic and diastolic BP was observed with low-dose ELE (500 mg/kg). Thus, $1000 \mathrm{mg} / \mathrm{kg}$ was selected as the effective dose and used in the actual study. In the preliminary study of $M$. oleifera extracts on NT rats, ELE, ALE, ERE, ETE, and ESE did not show significant reduction in systolic and diastolic BP on day 15 compared with that of the NC (Figure 2). a

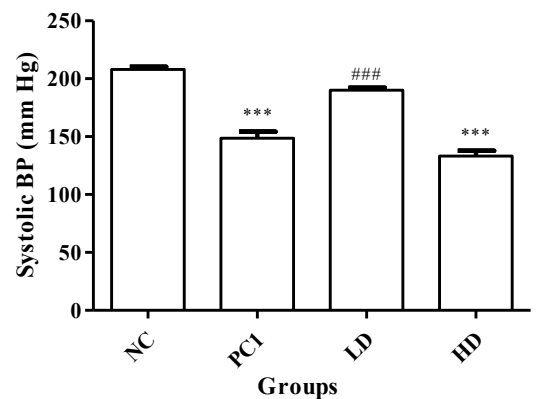

$\mathbf{b}$

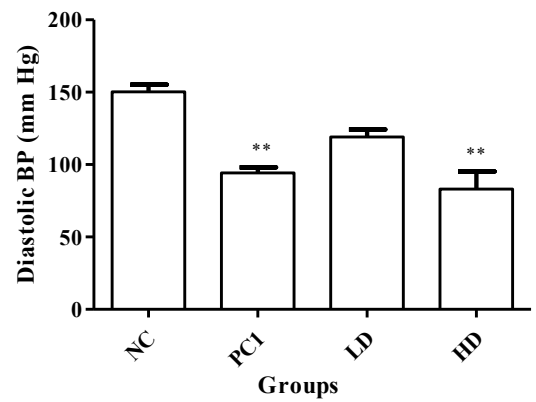

FIGURE 1. Systolic (a) and diastolic (b) BP of SH rats after 7 days of treatment with M. oleifera ethanolic leaf extracts (preliminary study). NC: negative control (spontaneously hypertensive (SH) rats without treatment), $\mathrm{PC1}$ : positive control (SH rats administered perindopril), LD: SH rats administered low-dose extract $(500 \mathrm{mg} / \mathrm{kg}), \mathrm{MD}$ : SH rats administered medium-dose extract (1000 mg/kg), HD: SH rats administered high-dose extract $(2000 \mathrm{mg} / \mathrm{kg}) .{ }^{*} p \leq 0.05,{ }^{* *} p \leq 0.01,{ }^{* * *} p$ $\leq 0.001$ compared with $\mathrm{NC} ; \# p \leq 0.05, \# \# p \leq 0.01, \# \# p \leq 0.001$ compared with $\mathrm{PC} 1 ; \mathrm{n}=3$

a

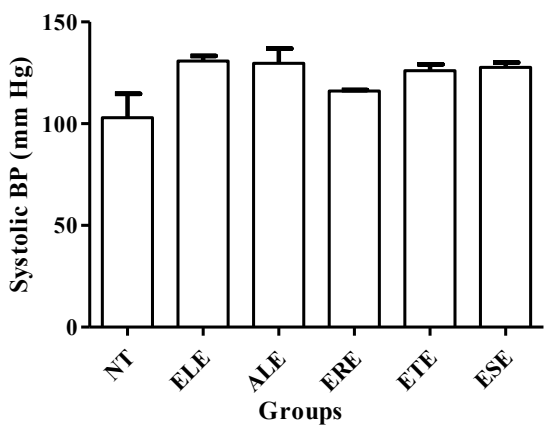

c

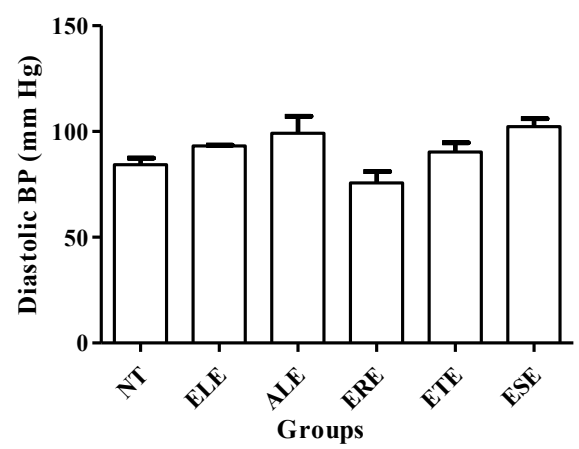

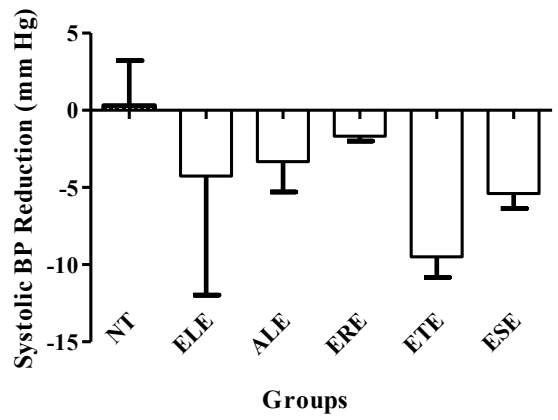

d

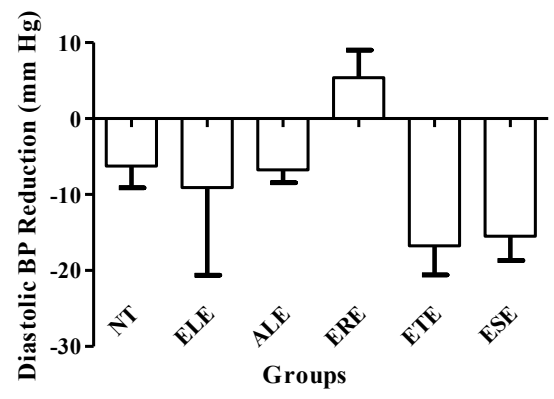

FIGURE 2. Systolic BP (a), systolic BP reduction (b), diastolic BP (c), and diastolic BP reduction (d) in NT rats after 14 days of treatment with Moringa oleifera plant part extracts (preliminary study). NT: normotensive rats (negative control), ELE: NT rats administered ethanolic leaf extract, ALE: NT rats administered aqueous leaf extract, ERE: NT rats administered ethanolic root extract, ETE: NT rats administered ethanolic twig extract, ESE: NT rats administered ethanolic seed extract; $* p$ $\leq 0.05, * * p \leq 0.01,{ }^{* * *} p \leq 0.001$ compared with $\mathrm{NT} ; \mathrm{n}=3$ 
In the actual study, compared with the NC rats, the systolic and diastolic BP (Figure 3) of SH rats treated with ELE $(121.40 \pm 5.11 \mathrm{~mm} \mathrm{Hg} ; 76.84 \pm 5.76$ $\mathrm{mm} \mathrm{Hg})$, ALE $(133.40 \pm 9.08 \mathrm{~mm} \mathrm{Hg} ; 98.05 \pm 7.33 \mathrm{~mm}$

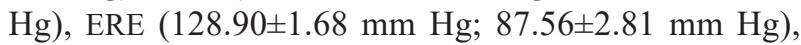
ETE $(123.30 \pm 3.31 \mathrm{~mm} \mathrm{Hg} ; 81.56 \pm 8.55 \mathrm{~mm} \mathrm{Hg})$, EPE $(139.30 \pm 8.56 \mathrm{~mm} \mathrm{Hg} ; 99.36 \pm 6.88 \mathrm{~mm} \mathrm{Hg})$, and EEE $(128.80 \pm 5.06 \mathrm{~mm} \mathrm{Hg} ; 95.87 \pm 3.50 \mathrm{~mm} \mathrm{Hg})$ significantly decreased after 14 days of treatment $(p \leq 0.05, p \leq$ $0.001)$. However, ESE $(134.90 \pm 13.41 \mathrm{~mm} \mathrm{Hg})$ and
APE $(126.70 \pm 19.68 \mathrm{~mm} \mathrm{Hg})$ only reduced systolic BP $(p \leq 0.01-p \leq 0.001)$ and not diastolic BP. Moreover, significant reductions in systolic and diastolic BP were observed with ELE $(81.88 \pm 7.22 \mathrm{~mm} \mathrm{Hg} ; 88.83 \pm 15.95$ $\mathrm{mm} \mathrm{Hg})$, ALE $(77.59 \pm 17.43 \mathrm{~mm} \mathrm{Hg} ; 67.93 \pm 21.14 \mathrm{~mm}$ $\mathrm{Hg})$, ERE (53.90 $\pm 1.22 \mathrm{~mm} \mathrm{Hg} ; 52.41 \pm 0.37 \mathrm{~mm} \mathrm{Hg})$, ETE $(71.87 \pm 6.33 \mathrm{~mm} \mathrm{Hg} ; 58.90 \pm 10.11 \mathrm{~mm} \mathrm{Hg})$, and EEE (53.68 $\pm 0.77 \mathrm{~mm} \mathrm{Hg} ; 48.63 \pm 0.52 \mathrm{~mm} \mathrm{Hg})(p \leq 0.01-p$ $\leq 0.001)$. In contrast, EPE $(47.08 \pm 8.63 \mathrm{~mm} \mathrm{Hg})$ reduced only systolic BP significantly $(p \leq 0.001)$ and not diastolic BP.

b

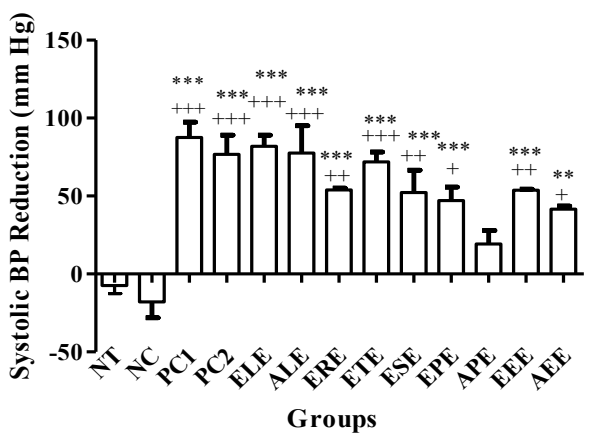

d

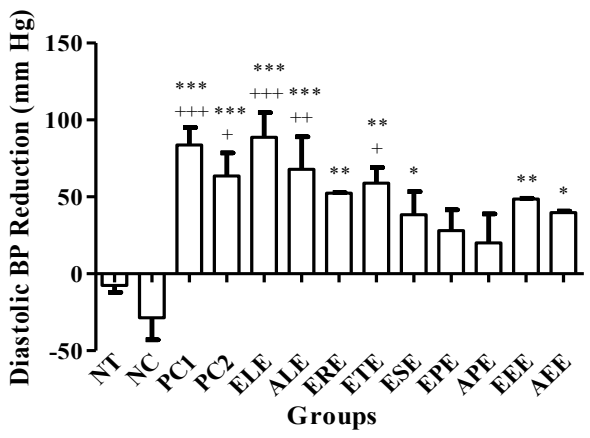

FIGURE 3. Systolic BP (a), systolic BP reduction (b), diastolic BP (c), and diastolic BP reduction (d) in SH rats after 14 days of treatment with Moringa oleifera plant part extracts (actual study). NT: normotensive rats, NC: negative control (spontaneously hypertensive (SH) rats without treatment), PC1: positive control ( $\mathrm{SH}$ rats administered perindopril), PC2: positive control (SH rats administered irbesartan), ELE: SH rats administered ethanolic leaf extract, ALE: SH rats administered aqueous leaf extract, ERE: SH rats administered ethanolic root extract, ETE: SH rats administered ethanolic twig extract, ESE: SH rats administered ethanolic seed extract, EPE: SH rats administered ethanolic pod extract, APE: SH rats administered aqueous pod extract, EEE: SH rats administered ethanolic stem extract, AEE: SH rats administered aqueous stem extract. $+p \leq 0.05,++p \leq 0.01,+++p \leq 0.001$ compared with NT; ${ }^{*} p \leq 0.05, * * p \leq 0.01, * * * p \leq 0.001$ compared with NC; $\mathrm{n}=5$

\section{DIURETIC ACTIVITY OF THE EXTRACTS}

Figure 4 shows a significant increase in the urine output of SH rats treated with hydrochlorothiazide $(6.36+1.14$
$\mathrm{mL})(p \leq 0.001)$ and $\operatorname{ELE}(5.14+0.49 \mathrm{~mL})(p \leq 0.01)$ compared with that of the NC. 


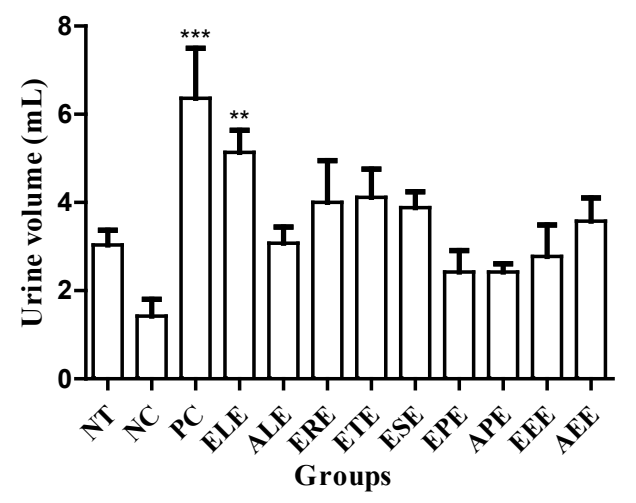

FIGURE 4. Total urine output of NT and SH rats after 14 days of treatment with Moringa oleifera plant part extracts (actual study). NT: normotensive rats, NC: negative control (spontaneously hypertensive (SH) rats without treatment), PC: positive control (SH rats administered hydrochlorothiazide), ELE: SH rats administered ethanolic leaf extract, ALE: SH rats administered aqueous leaf extract, ERE: SH rats administered ethanolic root extract, ETE: SH rats administered ethanolic twig extract, ESE: SH rats administered ethanolic seed extract, EPE: SH rats administered ethanolic pod extract, APE: SH rats administered aqueous pod extract, EEE: SH rats administered ethanolic leaf extract, AEE: SH rats administered aqueous stem extract. $* p \leq 0.05, * * p \leq 0.01, * * * p \leq 0.001$ compared with $\mathrm{NC} ; \mathrm{n}=5$

\section{ACE-INHIBITORY ACTIVITY OF THE EXTRACTS}

A preliminary study was conducted to determine the optimum concentration of extracts to be used in the study, and the results are shown in Figure 5. The lowest effective concentration of lisinopril (positive control) (36.50 $1.30 \%)$ in inhibiting ACE activity was $1 \mu \mathrm{g} / \mathrm{mL}$, and the highest concentration was $40 \mu \mathrm{g} / \mathrm{mL}$

$(88.60 \pm 2.90 \%)$, showing significant differences $(p<0.001)$ compared with the NC. For ELE, the lowest effective concentration was $40 \mu \mathrm{g} / \mathrm{mL}(46 \pm 3.97 \%)(p<0.05$ compared with the $\mathrm{NC})$ and the highest concentration was $80 \mu \mathrm{g} / \mathrm{mL}(57 \pm 9.75 \%)(p<0.01$ compared with the NC). Thus, concentrations of 40 and $80 \mu \mathrm{g} / \mathrm{mL}$ were used in this study. The inhibitory effect of the extracts on ACE activity was shown to be dose-dependent.

a

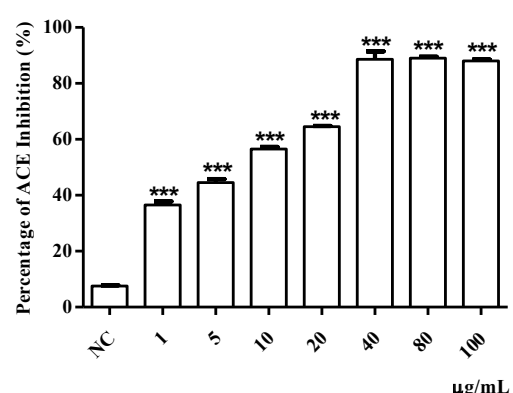

c

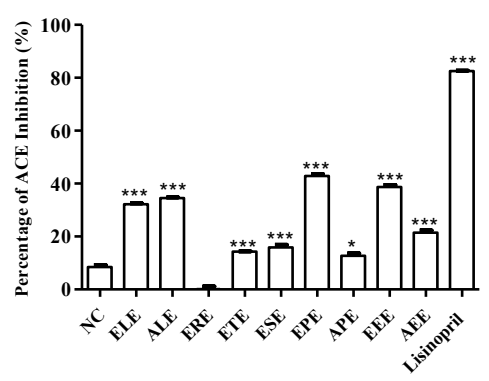

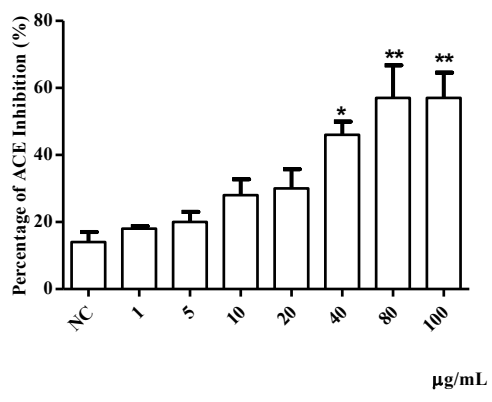

d

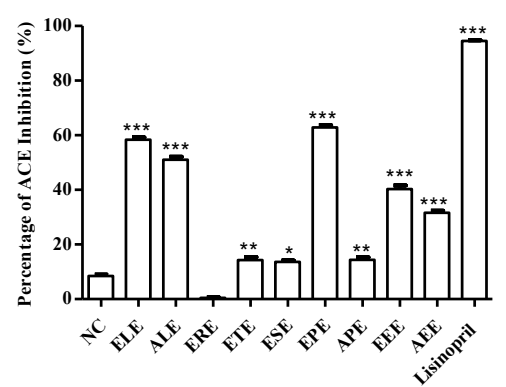

FIGURE 5. Mean percentage of angiotensin converting enzyme (ACE) inhibition after treatment with various concentrations of lisinopril (a) and ELE (b), as well as after treatment with $40 \mu \mathrm{g} / \mathrm{mL}$ (c) and $80 \mu / \mathrm{mL}$ (d) extract. NC: negative control (borate buffer), ELE: spontaneously hypertensive (SH) rats administered ethanolic leaf extract, ALE: SH rats administered aqueous leaf extract, ERE: SH rats administered ethanolic root extract, ETE: SH rats administered ethanolic twig extract, ESE: SH rats administered ethanolic seed extract, EPE: SH rats administered ethanolic pod extract, APE: SH rats administered aqueous pod extract, EEE: SH rats administered ethanolic stem extract, AEE: SH rats administered aqueous stem extract. * $p$ $<0.05,{ }^{* *} p<0.01,{ }^{* * *} p<0.001$ compared with $\mathrm{NC} ; \mathrm{n}=3$ 
Compared with the $\mathrm{NC}$, at $40 \mu \mathrm{g} / \mathrm{mL}, \mathrm{ELE}$ (32.24 $\pm 0.34 \%)$, ALE (34.56 $\pm 0.25 \%)$, ETE $(14.27 \pm 0.13 \%)$, ESE $(15.90 \pm 0.93 \%)$, EPE $(42.91 \pm 0.74 \%)$, APE $(12.72 \pm 0.94 \%), \operatorname{EEE}(38.68 \pm 0.82 \%)$, and AEE $(21.46 \pm 0.86 \%)$ significantly $(p \leq 0.01-p \leq 0.001)$ inhibited ACE activity. Furthermore, compared with that in the NC, ACE activity was significantly inhibited $(p \leq 0.01, p \leq$ $0.001)$ by ELE $(58.41 \pm 0.79 \%), \operatorname{ALE}(51.05 \pm 1.10 \%)$, ETE (14.31 \pm 1.05$)$, ESE (13.59 \pm 0.57$)$, EPE (62.84 $\pm 0.86 \%)$, APE (14.38 \pm 0.94$)$, EEE $(40.31 \pm 1.32 \%)$, and AEE $(31.61 \pm 0.81 \%)$ at $80 \mu \mathrm{g} / \mathrm{mL}$ (Figure 5).

\section{DISCUSSION}

$M$. oleifera is rich in various phytochemical compounds. In this study, the presence of these chemical markers was confirmed by the following standards: chlorogenic acid, $\beta$-sitosterol, stigmasterol, campesterol, and kaempferol3-O-rutinoside. Similar compounds have also been previously reported in various $M$. oleifera plant parts (Anwar et al. 2007; Leone et al. 2016; Ragasa et al. 2016; Sharma \& Paliwal 2013; Vongsak et al. 2014).

A preliminary study showed that $M$. oleifera extracts did not lower systolic and diastolic BP in NT rats. This indicates that this plant may not cause hypotension in healthy individuals. A similar effect was observed with garlic, which lowers BP in hypertensive patients, but not in healthy individuals (Wang et al. 2015). Nevertheless, further studies are required to extrapolate the results obtained in this study to humans.

The effective dose $(1000 \mathrm{mg} / \mathrm{kg})$ used in this study was obtained from a preliminary study conducted prior to the actual study. Among the tested extracts, compared with the NC, only AEE did not exert BP-lowering activity. Nevertheless, none of these extracts showed significant BP-lowering effects compared with the positive controls (perindopril and irbesartan); therefore, it was concluded that the BP-lowering effects of these extracts are comparable to those of the positive controls.

The hypotensive activity of $M$. oleifera leaf, seed, and root extracts in $\mathrm{SH}$ rat models has been reported (Gilani et al. 1994; Kajihara et al. 2008). However, to the best of our knowledge, extracts of the other parts of M. oleifera have not been investigated in SH rats. The observed hypotensive activity of ELE, ALE, ERE, ETE,
EPE, and EEE might be owing to the presence of bioactive compounds, such as niazinin A, niazinin B, niazimicin, niazimicin A, and B (Kajihara et al. 2008), nitrile, mustard oil glycosides, thiocarbamate glycosides (Anwar et al. 2007), 1,3-dibenzyl urea, aurantiamide (Sashidhara et al. 2009), and methyl p-hydroxybenzoate (Faizi et al. 1998). These bioactive compounds were isolated from the leaves, twigs, and pods of M. oleifera. Similar activity was also observed in the aqueous leaf extract of Moringa stenopetala, another species of Moringa (Mengistu et al. 2012).

On day 14 , the urine output of $\mathrm{SH}$ rats treated with ELE was comparable to that of those administered hydrochlorothiazide, with no significant difference. A similar pattern of diuresis was reported in M. oleifera root, leaf, and flower aqueous extracts (Cáceres et al. 1992). However, in the present study, the diuretic activity of aqueous root extract was not significant compared with that of the NC. The observed diuretic activity of ELE might be owing to the presence of polar compounds, such as flavonoids, saponins, and organic acids (Maghrani et al. 2005). These polar compounds might inhibit tubular reabsorption of water and ions into the renal tubules, thus causing diuresis (Patel et al. 2009). Taken together, diuretic activity might contribute to the hypotensive effect observed with ELE.

In the ACE-inhibitory assay, ELE, ALE, and EPE showed significant inhibitory effects, with the latter having the highest level of inhibition ( $>50 \%$ ) at $80 \mu \mathrm{g} / \mathrm{mL}$. The half-inhibitory concentrations $\left(\mathrm{IC}_{50}\right)$ of these active extracts are presented in Table 2 . The $\mathrm{IC}_{50}$ values of the three active extracts were significantly higher than that of lisinopril. This indicates that these extracts were effective in inhibiting ACE activity, but not as effective as lisinopril. The observed inhibitory effect might be owing to the presence of bioactive compounds, such as flavonoids (Ojeda et al. 2010), flavanols (Ottaviani et al. 2006), flavonols (Kwon et al. 2010), anthocyanins, isoflavones, flavones (Loizzo et al. 2007), and proteins (Garza et al. 2017). Similar ACE-inhibitory activities were observed in the seed (Garza et al. 2017) and leaf (Abdulazeez et al. 2017) extracts of $M$. oleifera. These extracts are worthy of further development, as harvesting of the leaves and pods for medicinal uses will not be destructive to the plant.

TABLE 2. $\mathrm{IC}_{50}(\mu \mathrm{g} / \mathrm{mL})$ values of lisinopril and plant extracts in inhibiting angiotensin converting enzyme activity

\begin{tabular}{cc}
\hline Substance & $\mathrm{IC}_{50}(\mu \mathrm{g} / \mathrm{mL})$ \\
\hline Lisinopril & $10.93 \pm 1.00$ \\
ELE & $58.65 \pm 1.55 * * *$ \\
ALE & $71.35 \pm 1.00^{* * *}$ \\
EPE & $54.04 \pm 1.00^{* * *}$ \\
\hline
\end{tabular}

ELE: spontaneously hypertensive (SH) rats administered ethanolic leaf extract, ALE: SH rats administered aqueous leaf extract, EPE: SH rats administered ethanolic pod extract. $* * * p<0.001$ compared with lisinopril 
Most of the studied plant extracts reduced systolic and diastolic BP in SH rats, but had no significant effect in NT rats. This is an interesting finding, as M. oleifera might not cause hypotension if consumed by individuals with normal BP. Moreover, diuresis was observed in $\mathrm{SH}$ rats treated with ELE, which indicates that diuresis might be a mechanism underlying the hypotensive effect of this plant extract. Some plant parts (ELE, ALE, and EPE) also showed good ( $>50 \%$ ) inhibitory effect on ACE activity, which might contribute to the observed hypotensive effect. The observed hypotensive effects might also be owing to the presence of bioactive compounds that act on BP and ACE activity. The other plant parts that did not show good diuretic and ACE-inhibitory activities but significantly reduced systolic and diastolic BP in $\mathrm{SH}$ rats may have different action mechanisms. Future research on active extracts of $M$. oleifera should focus on other action mechanisms associated with hypotension; examples include the calcium channel, angiotensin, and $\beta$ receptor-blocking activities. Active plant parts with known hypotensive effects can be potentially developed as dietary supplements for pre-hypertensive individuals.

\section{ACKNOWLEDGEMENTS}

The authors would like to thank Dr. Azmath Jaleel for his help in editing the manuscript and preparing the graphical abstract. This study was financially supported by the Ministry of Agriculture (MOA) of Malaysia (grant number: NH1015D073).

\section{REFERENCES}

Abdulazeez, A.M., Wudil, A.M. \& Yunusa, A.A. 2017. Effect of partially purified angiotensin converting enzyme inhibitory proteins from Moringa oleifera leaves on alloxan induced diabetic rats. Ife Journal of Science 19(1): 109-117.

Ab Majid, N.L., Omar, M.A., Khoo, Y.Y., Naidu, B.M., Yn, J.L.M., Rodzlan Hasani, W.S., Mat Rifin, H., Abd Hamid, H.A., Lourdes, T.G.R. \& Yusoff, M.F.M. 2018. Prevalence, awareness, treatment and control of hypertension in the Malaysian population: Findings from the National Health and Morbidity Survey 2006-2015. Journal of Human Hypertension 32(8-9): 617-624.

Agboola, S., Mofolasayo, O.A., Watts, B.M. \& Aluko, R.E. 2010. Functional properties of yellow field pea (Pisum sativum L.) seed flours and the in vitro bioactive properties of their polyphenols. Food Research International 43(2): 582-588.

Amaglo, N.K., Bennett, R.N., Lo Curto, R.B., Rosa, E.A.S., Lo Turco, V., Giuffrida, A., Lo Curto, A., Crea, F. \& Timpo, G.M. 2010. Profiling selected phytochemicals and nutrients in different tissues of the multipurpose tree Moringa oleifera L., grown in Ghana. Food Chemistry 122(4): 1047-1054.

Amiri, M., Majid, H.A., Mohd Hairi, F., Thangiah, N., Bulgiba, A. \& Su, T.T. 2014. Prevalence and determinants of cardiovascular disease risk factors among the residents of urban community housing projects in Malaysia. BMC Public Health 14(Suppl 3): S3.

Anwar, F., Latif, S., Ashraf, M. \& Gilani, A.H. 2007. Moringa oleifera: A food plant with multiple medicinal uses. Phytotherapy Research 21(1): 17-25.

Asare, G.A., Gyan, B., Bugyei, K., Adjei, S., Mahama, R., Addo, P., Otu-Nyarko, L., Wiredu, E.K. \& Nyarko, A. 2012. Toxicity potentials of the nutraceutical Moringa oleifera at suprasupplementation levels. Journal of Ethnopharmacology 139(1): 265-272.

Cáceres, A., Saravia, A., Rizzo, S., Zabala, L., De Leon, E. \& Nave, F. 1992. Pharmacologie properties of Moringa oleifera. 2: Screening for antispasmodic, antiinflammatory and diuretic activity. Journal of Ethnopharmacology 36(3): 233-237.

Dangi, S.Y., Jolly, C.I. \& Narayanan, S. 2002. Antihypertensive activity of the total alkaloids from the leaves of Moringa oleifera. Pharmaceutical Biology 40(2): 144-148.

Daugherty, A., Rateri, D., Hong, L. \& Balakrishnan, A. 2009. Measuring blood pressure in mice using volume pressure recording, a tail-cuff method. Journal of Visualized Experiments 15(27): 1291.

Fahey, J.W., Zalcmann, A.T. \& Talalay, P. 2001. The chemical diversity and distribution of glucosinolates and isothiocyanates among plants. Phytochemistry 56(1): 5-51.

Faizi, S., Siddiqui, B.S., Saleem, R., Aftab, K., Shaheen, F. \& Gilani, A.H. 1998. Hypotensive constituents from the pods of Moringa oleifera. Planta Medica 64(3): 225-228.

Faizi, S., Siddiqui, B.S., Saleem, R., Siddiqui, S., Aftab, K. \& Gilani, A.H. 1995. Fully acetylated carbamate and hypotensive thiocarbamate glycosides from Moringa oleifera. Phytochemistry 38(4): 957-963.

Faizi, S., Siddiqui, B.S., Saleem, R., Siddiqui, S., Aftab, K. \& Gilani, A.H. 1994. Isolation and structure elucidation of new nitrile and mustard oil glycosides from Moringa oleifera and their effect on blood pressure. Journal of Natural Products 57(9): 1256-1261.

Garza, N.G.G., Koyoc, J.A.C., Castillo, J.A.T., Zambrano, E.A.G., Ancona, D.B., Guerrero, L.C. \& García, S.R.S. 2017. Biofunctional properties of bioactive peptide fractions from protein isolates of moringa seed (Moringa oleifera). Journal of Food Science and Technology 54(13): 4268-4276.

Gilani, A.H., Aftab, K., Suria, A., Siddiqui, S., Salem, R., Siddiqui, B.S. \& Faizi, S. 1994. Pharmacological studies on hypotensive and spasmolytic activities of pure compounds from Moringa oleifera. Phytotherapy Research 8(2): 87-91.

Kajihara, R., Nakatsu, S., Shiono, T., Ishihara, M., Sakamoto, K. \& Muto, N. 2008. Antihypertensive effect of water extracts from leaves of Moringa oleifera Lam. on spontaneously hypertensive rats. Nippon Shok Kag Kog Kaish 55(4): 183 185.

Khare, C.P. 2007. Indian Medicinal Plants. New York: SpringerVerlag.

Kwon, E.K., Lee, D.Y., Lee, H., Kim, D.O., Baek, N.I., Kim, Y.E. \& Kim, H.Y. 2010. Flavonoids from the buds of Rosa damascena inhibit the activity of 3-hydroxy-3-methylglutarylcoenzyme a reductase and angiotensin I-converting enzyme. 
Journal of Agricultural and Food Chemistry 58(2): 882-886. Laurence, D.R. \& Bacharach, A.L. 1964. Evaluation of Drug Activities: Pharmacometrics. New York: Academic Press.

Leone, A., Spada, A., Battezzati, A., Schiraldi, A., Aristil, J. \& Bertoli, S. 2016. Moringa oleifera seeds and oil: Characteristics and uses for human health. International Journal of Molecular Science 17(12): 2141.

Lim, T.K. 2012. Edible Medicinal and Non-medicinal Plants. New York: Springer Dordrecht Heidelberg.

Loizzo, M.R., Said, A., Tundis, R., Rashed, K., Statti, G.A., Hufner, A. \& Menichini, F. 2007. Inhibition of angiotensin converting enzyme (ACE) by flavonoids isolated from Ailanthus excelsa (Roxb) (Simaroubaceae). Phytotherapy Research 21(1): 32-36.

Maghrani, M., Zeggwagh, N.A., Haloui, M. \& Eddouks, M. 2005. Acute diuretic effect of aqueous extract of Retama raetam in normal rats. Journal of Ethnopharmacology 99(1): 31-35.

Mahmood, K.T., Mugal, T. \& U1 Haq, I. 2010. Moringa oleifera: A natural gift-a review. Journal of Pharmaceutical Science Research 2(11): 775-781.

Mengistu, M., Abebe, Y., Mekonnen, Y. \& Tolessa, T. 2012. In vivo and in vitro hypotensive effect of aqueous extract of Moringa stenopetala. African Health Science 12(4): 545-551.

Ministry of Health (MOH). 2013. Clinical Practice Guidelines Management of Hypertension. Putrajaya: Malaysia.

Nadkarni, K.M. 2009. Indian Materia Medica. Bombay: Popular Book Depot.

Nellis, D.W. 1997. Poisonous Plants and Animals of Florida and the Caribbean. Florida: Pineapple Press, Inc.

Ojeda, D., Jiménez-Ferrer, E., Zamilpa, A., Herrera-Arellano, A., Tortoriello, J. \& Alvarez, L. 2010. Inhibition of angiotensin convertin enzyme (ACE) activity by the anthocyanins delphinidin- and cyanidin-3-O-sambubiosides from Hibiscus sabdariffa. Journal of Ethnopharmacology 127(1): 7-10.

Ottaviani, J.I., Actis-Goretta, L., Villordo, J.J. \& Farga, C.G. 2006. Procyanidin structure defines the extent and specificity of angiotensin I converting enzyme inhibition. Biochimie 88(3-4): 359-365.

Patel, U., Kulkarni, M., Undale, V. \& Bhosale, A. 2009. Evaluation of diuretic activity of aqueous and methanol extracts of Lepidium sativum garden cress (cruciferae) in rats. Tropical Journal of Pharmaceutical Research 8(3): 215-219.

Ragasa, C.Y., Ng, V.A.S. \& Shen, C.C. 2016. Chemical constituents of Moringa oleifera Lam. seeds. International Journal of Pharmacognosy \& Phytochemistry Research 8(3): 495-498.
Rathi, B.S., Bodhankar, S.L. \& Baheti, A.M. 2006. Evaluation of aqueous leaves extract of Moringa oleifera Linn for wound healing in albino rats. Indian Journal of Experimental Biology 44(11): 898-901.

Rossell, J.B. \& Pritchard, J.L.R. 1991. Analysis of Oilseeds, Fats and Fatty Foods. New York: Elsevier Applied Science.

Sashidhara, K.V., Rosaiah, J.N., Tyagi, E., Shukla, R., Raghubir, R. \& Rajendran, S.M. 2009. Rare dipeptide and urea derivatives from roots of Moringa oleifera as potential antiinflammatory and antinociceptive agents. European Journal of Medicinal Chemistry 44(1): 432-436.

Shanker, K., Gupta, M.M., Srivastava, S.K., Bawankule, D.U., Pal, A. \& Khanuja, S.P.S. 2007. Determination of bioactive nitrile glycoside(s) in drumstick (Moringa oleifera) by reverse phase HPLC. Food Chemistry 105(1): 376-382.

Sharma, V. \& Paliwal, R. 2013. Isolation and characterization of saponins from Moringa oleifera (Moringaeceae) pods. International Journal of Pharmacy \& Pharmaceutical Science 5(1): 179-183.

Siddhuraju, P. \& Becker, K. 2003. Antioxidant properties of various solvent extracts of total phenolic constituents from three different agro-climatic origins of drumstick tree (Moringa oleifera Lam). Journal of Agricultural and Food Chemistry 15(8): 2144-2155.

Vongsak, B., Sithisarn, P. \& Gritsanapan, W. 2014. Simultaneous HPLC quantitative analysis of active compounds in leaves of Moringa oleifera Lam. Journal of Chromatographic Science 52(7): 641-645.

Wang, H.P., Yang, J., Qin, L.Q. \& Yang, X.J. 2015. Effect of garlic on blood pressure: A meta-analysis. Journal of Clinical Hypertension 17(3): 223-231.

Drugs \& Herbal Research Centre

Faculty of Pharmacy

Universiti Kebangsaan Malaysia

Jalan Raja Muda Abdul Aziz

50300 Kuala Lumpur, Federal Territory

Malaysia

*Corresponding author; email: malina@ukm.edu.my

Received: 22 October 2019

Accepted: 26 August 2020 